\title{
Financial Reporting Practices in the Textile Manufacturing Sectors of Bangladesh
}

\author{
Md. Abdur Rouf ${ }^{1}$, Md. Salim Hasan', Alim Al Ayub Ahmed ${ }^{3}$ \\ ${ }^{1}$ Assistant Professor, Department of Business Administration, City University, BANGLADESH \\ ${ }^{2}$ Senior Lecturer, Department of Business Administration, Uttara University, BANGLADESH \\ ${ }^{3}$ Assistant Professor, Faculty of Business, ASA University Bangladesh, BANGLADESH
}

\begin{abstract}
The aim of this study is to examine the factors that influence companies to disclose voluntary information in their annual reports of Textile Manufacturing Companies in Bangladesh. The study is used ordinary least squares (OLS) regression model to examine the relationship between dependent variable and independent variables. The factors are proportion of independent non-executive directors (INDs), board size, board audit committee, ownership structure, Profitability and firm size. The extent of voluntary disclosure level is measured by using 68 items of information. Data have been taken from annual reports of 21 listed Textile Manufacturing Companies in DSE of Bangladesh-2010. The result shows a positive association between board size and voluntary disclosure and also total assets with voluntary disclosure. In contrast, the extent of voluntary disclosure is negatively related to the ownership structure.
\end{abstract}

Keywords: Corporate Governance, Voluntary Disclosure, Textile Companies, DSE

$10 / 13 / 2014$

Source of Support: Nil, No Conflict of Interest: Declared.

How to Cite: Rouf MA, Hasan MS and Ahmed AA. 2014. Financial Reporting Practices in the Textile Manufacturing Sectors of Bangladesh ABC Journal of Advanced Research, 3, 125-136.

This article is is licensed under a Creative Commons Attribution-NonCommercial 4.0 International License. Attribution-NonCommercial (CC BY-NC) license lets others remix, tweak, and build upon work non-commercially, and although the new works must also acknowledge \& be non-commercial.

\section{INTRODUCTION}

Published annual reports are required to provide various users - shareholders, employees, suppliers, creditors, financial analysts, stockbrokers, management, and government agencies - with timely and reliable information that is useful for making prudent, effective and efficient decisions. The annual report is a significant element in the overall disclosure process, because it is the most widely distributed source of information on publicly held corporations. The extent and quality of disclosure within these published reports vary from company to company and also from country to country. Although, the annual report is the major source of information to various user-groups, all the parts of the annual reports are not equally important to all users. Income statement is understood to be the most preferred section of the firm to investors and cash flow statement, balance sheet are more useful sections to bankers and creditors (Ho \& Wong, 2001). Similarly, users of accounting information evaluate audit reports, directors' reports, accounting policies and historical summary differently. The annual report should contain information that will allow its users to make correct decisions and efficient uses of limited resources. 
This study explores the extent and levels of voluntary disclosures in the annual reports of the listed Textile Manufacturing Companies in the Dhaka Stock Exchange (DSE) in Bangladesh, a developing country. The disclosure of voluntary information in annual reports is a key area of this research and specifically, voluntary disclosure has received a great attention to the academicians and several research is done both in developed (Bradbury, 1992 in New Zealand; Lim, S. et al (2007) in Australia; Hossain, Perera, \& Rahman, (1995) in New Zealand) and developing countries (Aktaruddin,M., et al. (2009) in Malaysia; Ferguson et al., 2002 in Hong Kong; Hossain \& Reaz, (2007) in India), however, a very few attention is done in the Middle East (Alsaeed, (2006) in Saudi Arabia; Naser et al. (2006) in Qatar; Al- Shammari, (2008) in Kuwait). The annual report is a significant element in the overall disclosure process, because it is the most widely distributed source of information on publicly held corporations.

In Bangladesh, both company law and securities and Exchange Rules govern corporate disclosure by listed companies in DSE. In Bangladesh, Company Act of 1994 and Securities and Exchange Rules of 1987 are two important legislations for corporate disclosure. The Companies Act 1994 provides the basic requirements for corporate disclosure and reporting applicable to all companies incorporated in Bangladesh (Government of Bangladesh, 1993). The Act requires companies to prepare financial statements in order to reflect a true and fair view of the state of affairs of the company. The Securities and Exchange Commission (SEC), another regulatory body, requires all listed companies to comply with accounting standards promulgated by the Institute of Chartered Accountants of Bangladesh (ICAB), in addition to its own disclosure provision (Government of Bangladesh, 1993). Disclosure provisions of the Security Exchange Rules are, in fact, restricted only to companies listed on the stock exchanges. It is often alleged. However; that company annual reports do not comply with the disclosure requirements stipulated by the regulatory agencies, resulting in poor disclosure compliance by the listed company (Akhtaruddin, M.(2005)

In addition, the Company Act requires companies to maintain proper books of account and to prepare and submit audited annual financial statements to their shareholders in order to reflect a "true and fair view" of the company's state of affairs. In terms of auditing, listed companies must prepare accounts in accordance with internationally accepted accounting principles and have them audited by independent auditors. Indeed, independent auditors' report has to be submitted in the company's annual general meeting (AGM) to the shareholders. The auditors shall report as to whether the relevant accounts show a true and fair view of the financial affairs of the body in question during the financial year in question and its assets and liabilities at the end of the year in question. Moreover, the auditor must audit the accounts of companies in light of generally accepted auditing standard (GAAS).

\section{ObJectives OF The Study}

The aim of this study is to examine the factors that influence companies to disclosure voluntary information in their annual reports of Textile Manufacturing Companies, Bangladesh. The specific objectives of the proposed study are:

- To measure the level of voluntary information disclosure by the listed Textile Manufacturing companies of DSE.

- To examine the association between firm's specific characteristics and corporate governances attributes with corporate voluntary disclosure levels of listed Textile Manufacturing companies of DSE. 


\section{Literature Review and Hypotheses DeVelopment}

A number of prior studies have investigated various determinants of companies' voluntary disclosure practices. The influence of Independent non-executive directors on corporate voluntary disclosure is an important predictor of corporate governance. Akhtaruddin, M. et al., (2009) the finding of their study is a positive association between the proportion of INDs and voluntary disclosure. Cheng and Courtenay (2006); Lim, S., et al. (2007); Rosario, M. and Flora, M. (2005) and Ho \& Wong (2001) also find that positive association between the number of outside non-executive disclosures and the extent of voluntary disclosure. Barako, D.G, et al. (2006) indicate the proportion of non-executive directors on the board is found to be significantly negatively associated with the extent of voluntary disclosure. Haniffa, R. M. and Cooke, T. E. (2002); Simon, S.M. H. and Kar, S. W. (2001); Ros, H \& Terry, C (2000) show that the chairman as non-executive director is negatively associated with the extent of voluntary disclosure.

Chau G.K. and Gray S.J. (2002) show that the extent of outside ownership is positively associated with voluntary disclosure. The results also indicate that the level of information disclosure is likely to be less in family controlled companies. Eng, L.L. \& Mak Y.T. (2003) shown that lower managerial ownership and significant government ownership are associated with increased disclosure. Gerald K. C. and Sidney J. G. (2002) find that there is a positive association between wider ownership and the extent of voluntary disclosure. The strong prevalence of "insider" and family-controlled companies is likely to be associated with lower levels of disclosure (Abdurrouf. M,2012). Ho \& Wong (2001) find a negative relation between family controlled firms and the level of voluntary disclosure. Hongxia, Li \& Ainian, Qi (2008) shown that firms with high managerial ownership have a high level of voluntary disclosure because capital structure with high managerial ownership decreases agency costs and increases the voluntary disclosure. Previous research provides evidence of a positive association between the presence of an audit committee and corporate disclosure practices (Barako, D.G. et al., 2006; Rosario, M. and Flora, M., 2005; Ho and Wong, 2001).

Haniffa, R. M. and Cooke, T. E. (2002) find that a positive and significant association between the firm's profitability and the extent of voluntary disclosure. Specifically, the chairman as non-executive director is negatively associated with the extent of voluntary disclosure. Hossain, M. and Hammami, H.(2009)indicate that profitability is insignificant in explaining the level of voluntary disclosure. Kusumawati, D. N. (2006) finds that profitability affects Good Corporate Governance voluntary disclosure level negatively.

Akhtaruddin, M. et al., (2009); Abdurrouf.M.(2011) find that board size is a positive association with voluntary disclosure. Cheng and Courtenay (2006) find that board size is not associated with voluntary disclosure.

Managers are motivated to disclosure more voluntary information to support the continuance of their positions and remuneration and to signal institutional confidence. Apostolos, K. et al., (2009); Karim, A.K.M.W.,(1996); Samir, M., (2003); Meek, et al.(1995) suggest that profitability of the companies are expected to disclose more voluntary information about their performance. Haniffa and Cooke (2002) find a positive and significant association between the firm's profitability and the extent of voluntary disclosure, which is consistent with the earlier (Leventis and Weetman, 2004; Kusumawati, D.N., 2006). Since the studies supporting positive relationship between profitability and voluntary disclosure are conducted in corporate disclosure field, the hypothesis of this study will be in the form of the positive relationship. 
H1: A higher proportion of independent non-executive directors on the board are positively associated with the level of voluntary disclosure.

$\mathbf{H}_{2}$ : The number of directors on a board is positively related to the level of voluntary disclosure.

$\mathbf{H}_{3}$ : The level of voluntary disclosure is positively associated with firms that have an audit committee.

$\mathbf{H}_{4}$ : The extent of voluntary disclosures is negatively associated with a higher management ownership.

H5: $_{5}$ The extent of voluntary disclosures is positively associated with the total assets.

H6: The extent of voluntary disclosures is positively associated with the total sales.

$\mathbf{H}_{7}$ : The extent of voluntary disclosures is positively associated with the profitability of the firm.

\section{DEsign OF the RESEARCh StUdy}

\section{Framework}

Considering all factors of the independents and dependent variables, the model of the study is depicted the following the table-1:

\section{Measurement}

Table-1: Framework

\begin{tabular}{|c|c|l|}
\hline $\begin{array}{c}\text { Dependant } \\
\text { variable }\end{array}$ & Definition & \multicolumn{1}{|c|}{ Measurement } \\
\hline TVDE & $\begin{array}{c}\text { Total Voluntary } \\
\text { Disclosure scores }\end{array}$ & $\begin{array}{l}\text { Total number of points awarded for voluntary } \\
\text { discloser, i.e., strategic, non-financial and } \\
\text { financial information(coding one "1" if the } \\
\text { company discloses and Zero "0" otherwise) }\end{array}$ \\
\hline $\begin{array}{c}\text { Independent } \\
\text { variables }\end{array}$ & Definition & \multicolumn{1}{|c|}{ Measurement } \\
\hline PIND & Independent director & $\begin{array}{l}\text { Percentage of independent non-executive } \\
\text { directors to directors on the board. }\end{array}$ \\
\hline BSZE & Board Size & Total Number of member on each board \\
\hline BAC & Board Audit Committee & 1 for Yes or 0 No \\
\hline PEOI & Ownership Structure & $\begin{array}{l}\text { Percentage of equity owned by the insiders to } \\
\text { all equity of the firm. }\end{array}$ \\
\hline TA & Total Assets & $\begin{array}{l}\text { The ratio of total debt of total equity value of } \\
\text { the firm }\end{array}$ \\
\hline TSE & Total Sales & $\begin{array}{l}\text { The ratio of net book value of fixed assets to } \\
\text { total assets }\end{array}$ \\
\hline NPA & Net Profit ability & Net profitability of the firm after Tax \\
\hline
\end{tabular}

\section{Sample Selection and Data Sources}

Sample is taken from annual reports of listed pharmaceutical and chemical companies on Dhaka Stock Exchange (DSE) Library on payment. The total number of companies cover under the study is 21 out of 30 as of 31st December-2010.All companies were considered for inclusive in the survey. The main criteria used for sampling the firms were: (i) annual reports must be available at the stock exchange and (ii) the firm must have been listed for the entire period of the study 2010. Nine companies were excluded because their annual reports were not available. (A List of the Textile Manufacturing Companies Listed in DSE in Appendix-1) 


\section{The Selection of Index- Weighted vs. Un-weighted}

Cooke (1989) mentions that there are two methods for determining the index of the level of corporate disclosure namely, weighted and unweighted. This is mainly because of the fact that not all the items mentioned in different disclosures are equally important. The relative importances of different items are different to different users. The unweighted method treats all the disclosable items are equally important (Akhtaruddin, 2005), Abdurrouf.M.(2011). Moreover, Wallace (1988) finds that all disclosure items are equally important to average users. Although there are different levels of users of disclosure items, the market trying to cope with the changing world should weigh all the mandatory items equally. If there is no provision in relevant laws regarding the relative importance, segregating is not feasible. The prior experiences of the weighted approach Akhtaruddin (2005) states that the weighted approach has, in fact, encountered several problems pointing out that the unweighted approach also has some limitations such as giving nil score for an item to the company that is not applicable for the company. However, the unweighted approach has got superiority supported by the research works done by Owusu-Ansah (1998) Wallace and Naser (1995). That is why this research is also carried out by the unweighted index, and this is here after known as ODI (Overall Disclosure Index

\section{Disclosure Index Construction}

The level of voluntary disclosure of the sample firms in this study was measured using a disclosure index that was developed in consultation with the disclosure checklist used by Akhtaruddin, M. (2009), Chau and Gray (2002), Ho and Wong (2001), and Ferguson, Lam and Lee (2002).

A total of 91 items were identified in compliance with voluntary disclosure items provided by listed firms in Bangladesh. These items were then compared with listing requirements for Dhaka stock exchange (DSE) and a mandatory disclosure checklist prepared by Akhtaruddin, M. (2005) in Bangladesh. Since the focus of this research is voluntary disclosures, the preliminary list of 91 items was subjected to a through selection to eliminate those that are mandated. This list was sent to various experts (professor, Professional Chartered accounted \& Cost and Management accounted etc.) for selection and as a result of their feedback, the initial list of 91 items was reduced to 68 items.

We employed an unweighted approach for the study. This approach is most appropriate when no importance is given to any specific user-groups (Hossain et al., 1994; Akhtaruddin, M. et al.,2009; Hossain, M. and Hammami, H.,2009). After establishing the disclosure index, a scoring sheet was developed to assess the extent of voluntary disclosure. If a company disclosed an item of information included in the index, it received a score of 1 , and 0 if it is not disclosed. The method of initially computing the disclosure score for each company can be expressed as follows:

$$
\begin{aligned}
\text { DCOR } & =\sum_{\mathrm{j}=1} \frac{\mathrm{dj}}{\mathrm{n}} \\
\text { DCOR } & =\text { the aggregate disclosures score; } \\
\mathrm{dj} & =1 \text { if the jth item is disclosed or } 0 \text { if is not disclosed; and } \\
\mathrm{n} & =\text { the maximum score each company can obtain. }
\end{aligned}
$$

\section{From of Regression model}

The following is the general form of the Ordinary Least Square (OLS) regression model which has been fitted to the data in order to assess the effect of each variable on the disclosure data associated with the aggregate disclosure index and to test the associated hypothesizes: 
$\mathrm{I}_{\mathrm{ij}}=\mathrm{a}+\beta_{1}$ Independent director $\mathrm{j}+\beta_{2}$ Board Size $_{\mathrm{j}}+\beta_{3}$ Board audit committee $_{\mathrm{j}}+\beta_{4}$

Where,

Ownership structure ${ }_{j}+\beta_{5}$ Firm's size $_{j}+\beta_{6}$ profitability $_{j}+\varepsilon$

I = the voluntary disclosure index for sampled companies

$\mathrm{i}$ = number of indices according to overall disclosure;

$\mathrm{j}=$ number of companies.

\section{FINDING AND DISCUSSION}

\section{Results of Descriptive Statistics Analysis}

Table-2: Descriptive Statistics for all Variables

\begin{tabular}{|c|c|c|c|c|}
\hline Variables & Mean & Minimum & Maximum & Std. Deviation \\
\hline TVD & 53.17 & 28 & 85 & 17.08 \\
PIND & 8.73 & 0 & 33 & 10.07 \\
BSZE & 7.63 & 6 & 10 & 1.12 \\
BAC & 0.47 & 0 & 1 & 0.513 \\
OST & 29.79 & 0 & 100 & 35.51 \\
TA & 9371.22 & 56.94 & 37168.12 & 11483.89 \\
TSE & 447.08 & 5.15 & 1727.69 & 571.22 \\
PA & 10.74 & 2 & 22 & 6.67 \\
\hline
\end{tabular}

Table-2 shows descriptive statistics for the sample firms. The results from the disclosure index indicate (TVD) the highest score achieved by a firm is $85 \%$ and the lowest score is $28 \%$ with a standard deviation of $17.08 \%$. So the firms are widely distributed with regard to voluntary disclosure. The mean of the proportion of independent non-executive directors (PIND) to the directors on the board is $8.73 \%$ with standard deviation is $10.07 \%$. The average board size (BSZE) is 7.63 with minimum and maximum sizes of 6 and 10 respectively. The average ownership structure (OST) is $29.79 \%$ with minimum and maximum sizes of $0 \%$ and $100 \%$ respectively. The average firm size is (Taka Bangladeshi) Tk.9371.22 lakh and Tk.447.08 lakh respectively in terms of total assets (TA) and total sales (TSE). The mean of the profitability of the sample firm is $10.74 \%$ with standard deviation is $6.67 \%$.

\section{Result of Pearson Correlation Analysis}

Table-3: Pearson Correlation analysis results

\begin{tabular}{|l|l|l|l|l|l|l|l|l|}
\hline Variable & TVD & PIND & BSZE & BAC & OST & TA & TSE & PA \\
\hline PIND & $.680^{* *}$ & 1.000 & & & & & & \\
\hline BSZE & $.650^{* *}$ & .357 & 1.000 & & & & & \\
\hline BAC & $.720^{* *}$ & $.725^{* *}$ & $.516^{*}$ & 1.000 & & & & \\
\hline OST & $-.950^{* *}$ & $-.670^{* *}$ & $-.467^{*}$ & $-.757^{* *}$ & 1.000 & & & \\
\hline TA & $.650^{* *}$ & -.050 & .285 & .275 & $.582^{* *}$ & 1.000 & & \\
\hline TSE & $.580^{* *}$ & -.140 & .244 & .292 & $-.555^{*}$ & $.901^{* *}$ & 1.000 & \\
\hline PA & $.680^{* *}$ & $.818^{* *}$ & $.524^{*}$ & $.753^{* *}$ & $-.670^{* *}$ & .044 & .142 & 1.000 \\
\hline ** Correlation is significant at the 0.01 level (2-tailed). \\
* Correlation is significant at the 0.05 level (2-tailed). \\
TVD = Total voluntary disclosure index for the sample firms. \\
PIND =Percentage of independent non-executive directors to directors on the board. \\
BSZE = Total number of member on each board. \\
BAC = Board audit committee, 1 for yeas or 0 No \\
OST = Percentage of the board owned by the internal management \\
TA = Total assets of the firm. \\
TSE = Total Sales of the firm. \\
PRFT = Net Profit of the firm.
\end{tabular}


Table-3: provides the Pearson product-moment correlation coefficients of the continuous explanatory variables, as well as the dependent variable included in the survey. The result of Pearson product-moment correlation exposed that independent director, board size, board audit committee, total assets, total sales and profitability are positively related with voluntary disclosure $(\mathrm{P}<0.01$, Two- tailed), but Percentage of board owned by the internal management of the firm is negatively related with voluntary disclosure $(\mathrm{P}<0.01$, Two- tailed). Percentage of independent directors is positively related with board audit committee and profitability and negatively related with the ownership structure $(\mathrm{P}<0.01$, Two- tailed).Board size is positively related with board audit committee and profitability and negatively related with the ownership structure $(\mathrm{P}<0.05$, Two- tailed). Board audit committee is positively related with profitability and negatively related with the ownership structure at the level of $(\mathrm{P}<0.01$, Two- tailed). The ownership structure is positively related with $\mathrm{TA}(\mathrm{P}<0.01$, Twotailed) and negatively with TSE $(\mathrm{P}<0.05$, Two- tailed) and PA $(\mathrm{P}<0.01$, Two- tailed). Total asset is also positively related with TSE $(\mathrm{P}<0.01$, Two- tailed).

\section{Results of Multiple Regression Analysis}

Table-4: Multiple Regression Results

\begin{tabular}{|c|c|c|c|c|}
\hline Variable & Coefficient & Standard Error & Bata t Values & Significance \\
\hline PIND & .203 & .356 & .860 & .408 \\
\hline BSZE & .153 & 1.225 & 2.027 & $.068^{*}$ \\
\hline BAC & .041 & 3.450 & .421 & .682 \\
\hline OST & -.450 & .081 & -2.838 & $.016^{* *}$ \\
\hline TA & .360 & .000 & 1.862 & $.090^{*}$ \\
\hline TSE & -.017 & .008 & -.067 & .948 \\
\hline PA & .091 & .474 & .518 & .615 \\
\hline \multicolumn{5}{|c|}{$\begin{array}{l}\text { R Square }=0.971 \text { Adjusted R Square }=0.953 \text { Durbin-Watson }=2.13 \\
* \mathrm{P}<0.1 \text {, two-tailed, } * * \mathrm{P}<0.05 \text {, two-tailed }\end{array}$} \\
\hline
\end{tabular}

The table-4: shows the association between voluntary disclosure index and experimental variables. The coefficient of coordination R-square, beta coefficients for the regression model and summarized results of the dependent variable on the explanatory variables can be seen in the table-4. The result indicates an R-square of 0.971 and adjusted R-square of 0.953 . Both of these values suggest that a significant percentage of the variation in voluntary disclosure can be explained by the variations in the whole set of independent variables.

If the independent variable PIND is one unit increased then this situation the dependent variable is decreased 0.21 with $\mathrm{SE}=0.356$, Beta $\mathrm{t}$ value $=0.860$ and significance at the 0.408 . The result suggests that firms have a higher proportion of INDs disclose is not associates with voluntary information. This result is similar to that of Barako, D.G. et al., (2006:5); Ho \&Wong (2001:75); Ros \& Terry (2000) who reported a negative association between the board composition variable and the extent of voluntary disclosure.

The next significant corporate governance variable is board size. The coefficient for board size is 0.153 and positive. It is statistically significant at the 0.068 level $(\mathrm{P}<0.1$, two-tailed) which suggests that a larger board is positively related to the level of voluntary disclosure. This result is similar to Abdur Rouf. M. (2011), Akhtaruddin. M et al., (2009), Zahra et al. (2000). The most significant corporate governance variable is the ownership structure. The regression coefficient for the variable is -0.450 , which is negative and statistically significant at the 0.016 level $(\mathrm{P}<0.05$, two-tailed). Which is similar with Hossain, et al.,(1994); Haniffa and Cooke,(2002); Akhtaruddin, M. et al.,(2009);Chau and Gary,(2002);Ho and Wong,(2001); Forker,(1992). 
With regard to control variables, our study suggests that are larger in size in respect to total assets that are positively related with the voluntary disclosures.

\section{CONCLUSIONS AND IMPLICATION FOR FURTHER STUDY}

This research is an extension of previous research where a set of corporate governance variables is considered to examine their association with the level of voluntary disclosure. The objective of this study was to examine corporate governance factors and their influence on voluntary disclosure in textile manufacturing companies. These factors include Proportion of independent non-executive directors on the board, board size, an audit committee, ownership structure, Profitability and firm size. In particular, the study aimed to determine which of these factors were significantly related to increased disclosure. The study used the disclosure index to measure voluntary disclosure on a sample of 21 listed companies of Bangladesh. The first hypothesis of the study was a higher proportion of independent non-executive directors on the board is positively related to the level of voluntary disclosure. But findings of my result show that it is negatively related to the proportion of independent non-executive directors. The results of the study show that the extent of voluntary disclosure is negatively related Percentage of the board owned by the internal management (OST). The findings of this research support it more that higher number of directors on a board is higher voluntary disclosure and the level of voluntary disclosure is associated positively with the total assets of the firm.

There are a number of limitations of this study as well. First limitation of the study is used only textile manufacturing companies as a sample. So, the results may not extend across all companies in Bangladesh. Second, the researchers' constructed disclosure index has been used in the study. The index is very sensitive and can affect the results if the selected items of information improperly. The results may differ across different years if multiple years are considered for analysis. Finally, the study investigates the extents of voluntary disclosure leaving the other facet of disclosure i.e., mandatory disclosure. The higher levels of voluntary disclosures, therefore, do not necessarily mean higher transparency. The results of the study should be interpreted with these limitations in mind.

Future research on voluntary disclosure should seek to take into account all listed companies under manufacturing sectors. Additionally, studying the same research issues found here but in a different industry sector would be an interesting extension of this study. This may disclose interesting results in terms of variations within the industrial sectors. Finally, future research should focus on the issues we raise in this paper using a disclosure index. This study covers the annual reports for a single year. Additional research is needed to assess the trends of voluntary disclosure and the quality of corporate governance over time.

\section{REFERENCES}

Abdurrouf. M. (2011) Ownership Structure and Voluntary Disclosure in Annual Reports of Bangladesh", Pakistan Journal of Commerce and Social Science, Volume-5, Number-1, 2011,Pp129-139

Abdurrouf. M. (2011) The Role of CEO, Board Composition and Firm Performance: An Empirical Study of Listed Companies in Bangladesh" Indian Journal of Commerce \& Management Studies, Volume-II, Issue-2, March-2011, pp-77-84

Abdurrouf. M. (2012) Ownership Structure, Audit Committee and Corporate Performance, Journal of the Institute of Cost and Management Accounts of Bangladesh, Volume-XL, Number-5, September-October, 2012, Pp-40-45 
Adams, C. A., Hill, W. and Roberts, C.B.(1998) Corporate Social Reporting Practices in Western Europe: Legitimating Corporate Behavior. British Accounting Review-30,1-21

Ahmed AA and Ahmad M. 2009. An Empirical Analysis of Performance Measurement of the Disclosure in Financial Reporting: A Study of Banking Sector in Bangladesh COMSATS Institute if Information Technology 2nd COMSATS International Business Research Conference. Lahore, Pakistan: CIIT.

Ahmed AA and Dey MM. 2011. Accounting Disclosure Scenario: An Empirical Study of the Banking Sector of Bangladesh Accounting \& Management Information Systems, 9.

Ahmed AA, Dey MM, Akhter W and Raza A. 2011. Timeliness attributes and the extent of accounting disclosure: a study of banking companies in Bangladesh Interdisciplinary Journal of Contemporary Research in Business, 3, 915-925.

Ahmed AA, Khan W and Hossain MS. 2011. Reporting Practice of Accounting Disclosure on Changes in Listed Companies of Bangladesh ASA University Review, 5, 83-96.

Ahmed AA. 2012. Disclosure of Financial Reporting and Firm Structure as a Determinant: A Study on the Listed Companies of DSE ASA University Review, 6, 44-60.

Ahmed, K. and John, K. C. (1999) Associations between Corporate Characteristics and Disclosure Levels in Annual Reports: A Meta-Analysis, British Accounting Review (1999) 31, 35-61

Akhtaruddin, M., Hossain, M. A., Hossain, M. \& Yao Lee (2009) Corporate Governance and Voluntary Disclosure in Corporate Annual Reports of Malaysian Listed Firms, The Journal of Applied Management Accounting Research, Vol-7 Number-1, 2009

Akhtaruddin, M.,(2005) Corporate mandatory disclosure practices in Bangladesh, The International Journal of Accounting 40(2005) 399-422

Alsaeed Khalid (2006) The association between firm-specific characteristics and disclosure: The case of Saudi Arabia, Managerial Auditing Journal: 2006 Volume: 21 Issue: $\underline{5}$ Page: 476 - 496

Al-Shammari, B. (2008). Voluntary disclosure in Kuwait corporate annual reports, Review of Business Research, 1,10-30.

Apostolos, K. A. and Konstantinos, A.N. (2009) Voluntary accounting disclosure and corporate governance: evidence from Greek listed firms, International Journal of Accounting and Finance 2009 - Vol. 1, No.4 pp. 395 - 414

Barako, D.G., Hancock, P. \& Izan, H. Y (2006) Factors influencing voluntary corporate disclosure by Kenyan companies, Corporate Governance: An International Review 14 (2): 107-125.

Bradbury, M.E.(1992) Voluntary disclosure of financial segment data: New Zealand evidence, Accounting and Finance, 32, 15-26

Bruce, J. M. and Merridee, B. (2006) Corporate Governance: Factors Influencing Voluntary Disclosure by Publicly Traded Canadian Firms, Canadian Academic Accounting Association.

Chau, GK and Gray, SJ (2002) Ownership structure and corporate voluntary disclosure in Hong Kong and Singapore, The International Journal Account.37:247-265

Chen, C. J. P., and Jaggi, B. (2000) Association between independent non-executive directors, family control and financial disclosures in Hong Kong, Journal of Accounting and Public Policy 19 (4-5): 285-310.

Cheng and Courtenay (2006) Board composition, regulatory regime and voluntary disclosure, The International Journal of Accounting 41 (3): 262-289.

Eng, L. L., and Mak, Y. T. (2003) Corporate governance and voluntary disclosure, Journal of Accounting and Public Policy 22 (4): 325-345.

Ferguson, M. J., Lam, K. C., \& Lee, M. G. (2002) Voluntary disclosure by state-owned enterprises listed on the stock exchange of Hong Kong. Journal of International Financial Management and Accounting, 13(2), 125-152 
Gerald K. C and Sidney J. G (2002) “Ownership structure and corporate voluntary disclosure in Hong Kong and Singapore", The International Journal of Accounting, Volume 37, Issue 2 , 2002, Pages 247-265

Haniffa, R. M., and T. E. Cooke (2002) Culture, corporate governance and disclosure in Malaysian Corporations, Abacus 38 (3): 317-349

Ho \& Wong (2001)A study of corporate disclosure practices and effectiveness in Hong Kong, Journal of International Financial Management and Accounting, 12(1), 75-101.

HongxiaLi \& Ainian Qi (2008) Impact of Corporate Governance on Voluntary Disclosure in Chiness Listed Companies, Corporate Ownership \& control/ Volume-5, Inssue-2, Winter-2008.

Hossain, M. and Hammami, H.(2009)Hossain, M., \& Reaz, M. (2007) Determinants and characteristics of voluntary disclosure by Indian banking companies, Corporate Social Responsibility and Environmental Management Corp. Soc. Responsibility, Environment Management, 14(5), 274-288

Hossain, M., Perera, M.H.B., \& Rahman, A.R.(1995) Voluntary disclosure in the annual reports of New Zealand companies, Journal of International Financial Management and Accounting,6, 69-87.

Hossain,M., Tan, L.M., \& Adams,M. (1994). Voluntary disclosure in an emerging capital market: Some empirical evidence from companies listed on the Kuala Lumpur Stock Exchange. The International Journal of Accounting, 29, 334-351

Karim, A.K.M.W (1996) The association between corporate attributes and the extent of corporate disclosure, Journal of Business Studies, University of Dhaka, 17(2), 89-124.

Kusumawati, D. N (2006) Profitability and Corporate Governance Disclosure: An Indoneian Study. Simposium Nasional Akuntansi-9 Padahg, 23-26 Agustus, K-INT-14, pp-1-19

Leventis, S. and Weetman, P.(2004)Voluntary Disclosures In An Emerging Capital Market: Some Evidence From The Athens Stock Exchange , Advances in International Accounting, Volume 17, 2004, Pages 227-250

Lim, S., Matolcsy, Z. and Chow, D. (2007) Association between Board Composition and Different Types of Voluntary Disclosure, European Accounting Review, Forthcoming, July 12, 2007

Marston, C., \& Robson, P. (1997) Financial reporting in India: Changes in disclosure over the period 1982 to 1990. Asia-Pacific Journal of Accounting, 4(6), 109-139

Meek, G. K., Roberts, C. B., \& Gray, S. J. (1995) Factors influencing voluntary annual report disclosures by U.S., U.K. and continental European multinational corporations, Journal of International Business Studies, 26(3), 5-572

Naser, K., Al-Hussaini, A., Al-Kwari, D., \& Nuseibeh, R. (2006) Determinants of corporate social disclosure in developing countries: The case of Qatar. Advances in International Accounting, 19,1-23.

New. D., Warsame, H. \& Pedwell, K. (1998) Managing Public Impressions: Environmental Disclosures in Annual Reports, Accounting, Organizations and Society, Vol.23, No.3, P-265-282

Obeua S Persons (2009) Audit committee characteristics and earlier voluntary ethics disclosure among fraud and no-fraud firms, International Journal of Disclosure and Governance (2009) 6, 284-297

Ros, H \& Terry, C (2000) Culture, Corporate Governance and Disclosure in Malaysian Corporations, The Asian AAA World Conference in Singapore, 28-30 August 2000.

Rosario, M. and Flora, M. (2005)Corporate Characteristics, Governance Rules and the Extent of Voluntary Disclosure in Spain, Advances in Accounting, Volume 21, 2005, Pages 299-331

Samir, M, James, E. G. \& Fornaro, M. (2003) An Empirical Investigation of Corporate Voluntary Disclosure of Management's Responsibilities for Financial Reporting, Lubin School of Business Faculty Working Papers, Pace University

Simon, S.M. H. and Kar, S. W (2001) A study of the relationship between corporate governance structures and the extent of voluntary disclosure, Journal of International Accounting, Auditing and Taxation, Volume 10, Issue 2, Summer- 2001, Pages 139-156 
Voluntary disclosure in the annual reports of an emerging country: The case of Qatar, Advances in International Accounting, Volume 17, 2009, Pages 227-250

Wang Xue (2008) Voluntary Disclosure Behavior and Strategy in Chinese Listed Companies, Journal of Modern Accounting and Auditing, ISSN 1548 -6583, USA, Vol.4 (Serial No. 35)

\section{APPENDEX-1:}

List of the Textile Manufacturing Companies Listed in DSE

\begin{tabular}{|c|l|}
\hline S.N. & \multicolumn{1}{|c|}{ Name of the Companies } \\
\hline 1. & Al-Haj Textile \\
\hline 2 & Alltex Industries Ltd. \\
\hline 3. & Anlimayarn Deying Ltd. \\
\hline 4. & Apex Spinning \& Knitting Mills Limited \\
\hline 5 & Argon Denims Limited \\
\hline 6. & CMC Kamal \\
\hline 7. & The Dacca Dyeing \& Manufacturing Co.Ltd. \\
\hline 8. & Delta Spinners Ltd. \\
\hline 9. & Desh Garmants \\
\hline 10. & Dulamia Cotton \\
\hline 11. & Envoy Textiles Limited \\
\hline 12. & Familytex (BD) Limited \\
\hline 13. & Generation Next Fashions Limited \\
\hline 14. & H.R.Textile \\
\hline 15. & Maksons Spinning Mills Limited \\
\hline 16. & Malek Spinning Mills Ltd. \\
\hline 17. & Metro Spinning \\
\hline 18. & Mithun Knitting \\
\hline 19. & Modern Dyeing \& Screen Printing Ltd. \\
\hline 20. & Prime Textile \\
\hline 21. & Rahim Textile \\
\hline 22. & R.N. Spinning Mills Limited \\
\hline 23. & Safko Spinnings \\
\hline 24. & Saiham Cotton Mills Limited \\
\hline 25. & Saiham Textile \\
\hline 26. & Sonargaon Textiles \\
\hline 27. & Square Textile \\
\hline 28. & Stylecraft Limited \\
\hline 29. & Tallu Spinning \\
\hline 30. & Zahintex Industries Limited \\
\hline & \\
\hline & \\
\hline 19
\end{tabular}


Publish Online and Print Version Both

ISSN Online: 2312-203X 